\title{
Fruit and Vegetable Street Vendors in Urban Informal Sector in Hyderabad, India
}

\author{
A. Samarpitha* \\ Department of Agricultural Economics, Agricultural College, Warangal, \\ PJTSAU, Telangana, India \\ *Corresponding author
}

\section{A B S T R A C T}

\section{Keywords}

Street vendors, Urban informal sector, Fruit and vegetable vendors, Hyderabad, Telangana

\section{Article Info}

Accepted:

10 October 2019

Available Online:

10 November 2019
In the Indian labour market $81 \%$ of the total employed is in informal sector, followed by only $6.5 \%$ in the formal sector and $0.8 \%$ in the household sector. Major groups of urban informal workers in Indian cities are categorised as home-based workers, street vendors, waste pickers and domestic workers. In India, street vending makes up 14 per cent of total urban informal employment. Fruit and vegetable vendors make up the maximum share of the total street vendors in Telangana. Hence this paper attempts to study the fruit and vegetable street vendors in Hyderabad, the capital city of Telangana. This study revealed that most of the street vendors were male, middle aged having small families, educated with experience of less than 10 years in street vending. The time spent in street vending ranged from 6 to 15 hours per day. Majority of the respondents raised their capital for initial investment from individual savings, earned Rs. 100-300 per day and reported that the performance of their business was satisfactory. For majority of respondents the business of street vending was inherited from parents. Major constraints in street vending were fear of eviction by municipality officials, lack of formal license, lack of hygienic storage facilities, lack of permanent space for vending, price fluctuation of fruits and vegetables, competition from other street vendors, organized retail sector and facing the adverse weather conditions.

\section{Introduction}

More than $60 \%$ of the employed population in the world and $68.2 \%$ in Asia-Pacific countries earns their livelihoods in the informal economy. Among the five South Asian countries, informalisation of labour is highest in Nepal $(90.7 \%)$ followed by India $(81 \%)$, Pakistan (77.6\%), Sri Lanka (60.6\%) and
Bangladesh (48.9\%) (ILO, 2018). Most people enter the informal economy not by choice but as a consequence of lack of opportunities in the formal economy and in the absence of other means of livelihood (ILO, 2017). According to Centre for Monitoring Indian Economy (CMIE), the overall unemployment rate as of $29^{\text {th }}$ October, 2019 is $8.1 \%$ across India with $9.4 \%$ in the urban parts of the 
country and $8.2 \%$ in the rural regions. Though the informal economy in India is estimated to diminish in size as formal employment expands, contrary to this, the trends have shown that informal sector economy is thriving in India.

In India the total share of informal employment was $78 \%$ in $1999-00$ whereas it increased to $81 \%$ in 2016-17. In the Indian labour market $81 \%$ of the total employed is in informal sector, followed by only $6.5 \%$ in the formal sector and $0.8 \%$ in the household sector (ILO, 2018). Urban informal workers are present mostly in cities. Major groups of urban informal workers in Indian cities are categorised as home-based workers, street vendors, waste pickers and domestic workers (Raveendran, 2011).

In India, street vending makes up 14 per cent of total urban informal employment (Chen, and Raveendran, 2011). A street vendor is broadly defined as a person who offers goods or services for sale to the public without having a permanent built up structure but with a temporary static structure or mobile stall or head load (NPUSV, 2009). The vendors provide a wide array of goods and commodities to the urban populace at reasonable prices and convenient locations. The type of goods they sell makes an interesting study - from daily needs like vegetables, fruits, fish, meat and snacks to occasional needs like flowers and readymade garments (www.nasvinet.org).

India is the second-largest fruit and vegetable producer, accounting for $10.9 \%$ and $8.6 \%$ of the world fruit and vegetable production respectively (FAO). It is also one of the largest consumer markets, with food and grocery having the largest share of $31 \%$ in the consumption basket (www.ibef.org). The marketing of fruits and vegetables is characterised by a diversity of distribution chains, including formal markets, street vendors, shops and supermarkets. A study conducted by Indian Council for Research on International Economic Relations (ICRIER) found that Indian consumers preferred to buy fruits and vegetables from the local markets (53.3 per cent) and push carts (18.8 per cent). Majority (56 per cent) of the respondents were willing to purchase non-branded fruits and vegetables as they feel that branded products were over-priced, contain preservatives and were not always fresh and chemical free (Arpita et al., 2016).

Telangana, the $12^{\text {th }}$ largest state in India in terms of both area and population with $61.12 \%$ of rural and $38.38 \%$ of urban population respectively is becoming one of the fastest urbanizing states in the country where the urban population grew by $38.12 \%$ during the decade 2001 to 2011 compared to $2.13 \%$ growth in rural population (www.tsccc.eptri). Around $30 \%$ of the total urban population in the state is residing in the capital city of Hyderabad alone which offers varied employment opportunities attracting people from various parts of the country resulting in diverse food habits in the state. Various studies have shown the shift in food consumption pattern in India over the years (Kumar and Mathur, 1996; Kumar et al., 2007; Mittal, 2007; Ray, 2007; Arpita et al., 2016). As the income increases people tend to replace cereals and diversify their food basket with fruits, vegetables and animal products. Therefore the shifts in food habits are more conspicuous in urban areas compared to rural areas (Kumar et al., 2007).

According to the report on Food Consumption Pattern in Telangana State-2017, people in Telangana spend Rs.2156 towards food consumption per month of which the expenditure on fruits and vegetables is Rs.182 and Rs.277 per month respectively. Amount spent on apple comprised about $33 \%$ of total 
fruit expenditure followed by pomegranate $(13 \%)$. While in terms of quantity, banana $(0.514 \mathrm{~kg})$ leads fruit consumption. However, a rural consumer eats just one-third of fruits as that of urban consumer. Among vegetables, onion and tomato occupy a major share with a monthly per capita consumption quantity (MPCQ) of about $1 \mathrm{~kg}$ each followed by potato (510g) (Sanjiv et al., 2017).

A study conducted by Telangana Mission for Elimination of Poverty in Municipal Areas (TMEPMA) in 2017 revealed that fruit $(15.99 \%)$ and vegetable vendors $(24.42 \%)$ make up the maximum share $(40.41 \%)$ of the total street vendors surveyed (36076) in Telangana (www.tmepma.cgg.gov.in). Hence this paper attempts to specifically study the fruit and vegetable street vendors in Hyderabad with the following objectives:

To study the socio-economic characteristics of street vendors.

To analyse the reasons for taking up for street vending.

To study the problems in street vending.

\section{Materials and Methods}

The data of the selected street vendors were obtained through personal interview method with the help of pre-tested comprehensive interview schedule during the year 2016. The primary data regarding socio-economic characteristics of the sample respondents were collected from street vendors located in Hyderabad along with the information on reasons for taking up street vending, performance of the business, problems faced. A total sample size of 60 fruit and vegetable street vendors has been considered for this study. Descriptive/tabular analysis involving the computation of means and percentages were employed to present the data.

\section{Results and Discussion}

The primary data regarding socio-economic characteristics such as gender, age, family size, educational profile, years of experience in street vending have been studied and the results are presented in Table 1.

It was found that the majority of the respondents were male having mean age of 37.75 years. Most $(63.33 \%)$ of the families of respondents were small in size. It was noticed that $75 \%$ of the respondents were educated. Majority of the respondents were in the business of street vending since 10 years while only $12 \%$ had experience of more than 30 years. It was found that $93 \%$ of the respondents were married. The occupation of the spouse of vendors varied with majority $(66.67 \%)$ being housewives. $13.33 \%$ worked as street vendors and wage workers and $6.67 \%$ were auto drivers. Before starting street vending, the respondents were working as either daily wage workers, home based workers, cab driver, auto driver, domestic workers, cook in hospital or worker in canteen.

\section{Operations}

The time spent in street vending ranged from a minimum of 6 hours to a maximum of more than 15 hours per day. Most of the vendors started their business at $7 \mathrm{AM}$ to $8 \mathrm{AM}$ and continued up to $9 \mathrm{PM}$ or $10 \mathrm{PM}$. The time spent in cleaning the premises for street vending ranged from half an hour to 2 hours. Most of the respondents stayed within $4 \mathrm{~km}$ of the vending place and they would travel by walk or bike or bus or auto from their residence to work place. There was no proper storage facility for storing the leftover fruits and vegetables. Most of the vendors stored their goods at the same place or at their home or in the pushcarts by covering the fruits and vegetables with wet gunny bags or store in a 
small room of a nearby retailer by paying monthly rent. Some vendors reported that they would sell the leftover stock of the day to small retailers.

The major source of capital for initial investment for the business was raised from individual savings for $36.67 \%$ of the respondents, followed by borrowing from local money lenders on interest (31.67\%), family, relatives and friends $(13.33 \%)$, loans from Self Help Groups (11.67\%) and loan from banks $(6.67 \%)$ as shown in Figure 1. The daily income ranged from Rs. 100-300 for $56.67 \%$ of the respondents followed by Rs.500-1000 for 30\% and Rs.300-500 for $13.33 \%$ of the respondents.

The vendors reported that they bought the fruits from the wholesale fruit market and vegetables from rythu bazaars and sold them for a profit margin of 10-20\%. Majority $(36.67 \%)$ of the respondents reported that the performance of their business was satisfactory whereas $30 \%$ said it was at break-even point i.e., no profit-no loss. $18.33 \%$ reported loss and only $15 \%$ reported that the performance of their business was good.

\section{Reasons for taking up street vending}

The reason cited by most of the respondents $(38.33 \%)$ for taking up street vending was because this business was handed over to them by their parents and grandparents while $25 \%$ of them started street vending as it needs low initial investment. $13.33 \%$ started street vending in need of income for survival. Nearly $7 \%$ of the respondents reported that difficulty in finding a salaried job and failure of agriculture in villages compelled them to migrate to city and take up street vending. Only 5\% opined that they took up street vending because it is easy to enter into street vending business and also because it provides flexibility in working (Fig. 2).

\section{Problems faced by street vendors}

The most frequently faced problem by the street vendors was eviction by the Greater Hyderabad Municipal Corporation (GHMC) officials as reported by $28 \%$ of the respondents who said they had to offer bribe to the officials in the form of cash or kind (fruits and vegetables) in order to avoid eviction. Need for a formal license for street vendors was felt by $21 \%$ of the respondents. Since fruits and vegetables are highly perishable in nature, they tend to quickly deteriorate if not sold within a day or two. In such situations, $14 \%$ of the respondents felt that there is a need for hygienic storage facilities to avoid quantitative and qualitative losses. Lack of permanent space for vending was a problem for $12 \%$ of the respondents.

Another challenge was price fluctuation of fruits and vegetables leading to uncertainty in profits as reported by $11 \%$ of the street vendors. Competition from other street vendors and organized retail sector was also perceived as a threat by $6 \%$ and $3 \%$ of the street vendors respectively. Facing the adverse weather conditions such as heat, cold, rains etc in open also was a serious threat to the health as mentioned by $5 \%$ street vendors.

There is an urgent need to tackle informality. For hundreds of millions of workers, informality means a lack of social protection, rights at work and decent working conditions, and for enterprises it means low productivity and lack of access to finance. Data on those issues are crucial for designing appropriate and integrated policies that are tailored to the diversity of situations and needs (ILO, 2018).

This study revealed that most of the street vendors were male, middle aged having small families, educated with experience of less than 10 years. The time spent in street vending ranged from 6 to 15 hours per day. 
Table.1 Socio-economic characteristics of the sample street vendors

\begin{tabular}{|c|c|c|}
\hline Particulars & $\begin{array}{c}\text { Number of } \\
\text { respondents }\end{array}$ & $\begin{array}{c}\text { Percentage of total } \\
\text { sample }\end{array}$ \\
\hline Gender & 48 & \\
\hline Female & 12 & 80.00 \\
\hline Age group & & 20.00 \\
\hline Young (<30 years) & 23 & 38.33 \\
\hline Middle (30-50 years) & 30 & 50.00 \\
\hline Old (>50 years) & 7 & 11.67 \\
\hline Mean age (years) & 37.75 & \\
\hline Family size & & \\
\hline Small (1-4) & 38 & 63.33 \\
\hline Medium (5-7) & 19 & 31.67 \\
\hline Large (>8) & 3 & 5.00 \\
\hline Educational profile & & \\
\hline Illiterate & 15 & 25.00 \\
\hline Below SSC & 23 & 38.33 \\
\hline SSC to Intermediate & 22 & 36.67 \\
\hline Experience in street vending & & \\
\hline Up to 10 years & 38 & 63.33 \\
\hline 11 to 20 years & 12 & 20.00 \\
\hline 21 to 30 years & 3 & 5.00 \\
\hline >30 years & 7 & 11.67 \\
\hline Mean experience & 11.3 years \\
\hline
\end{tabular}

Source: Primary data

Fig.1 Source of capital for investment

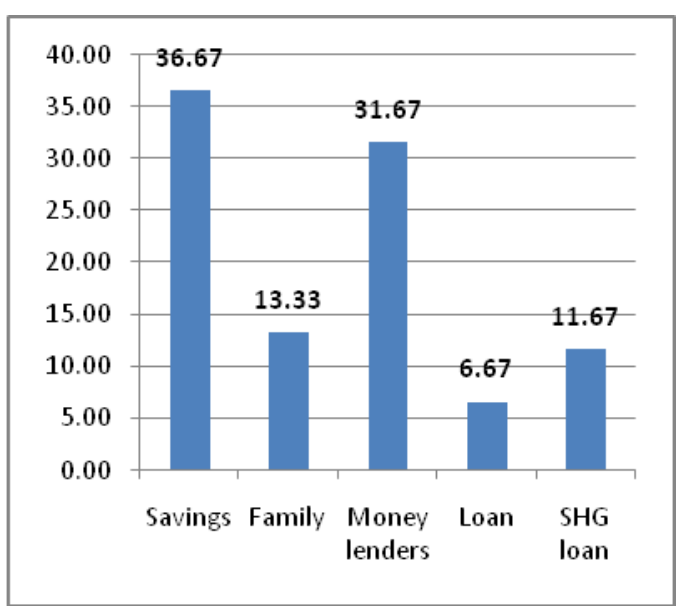

Fig.2 Reasons to take up street vending

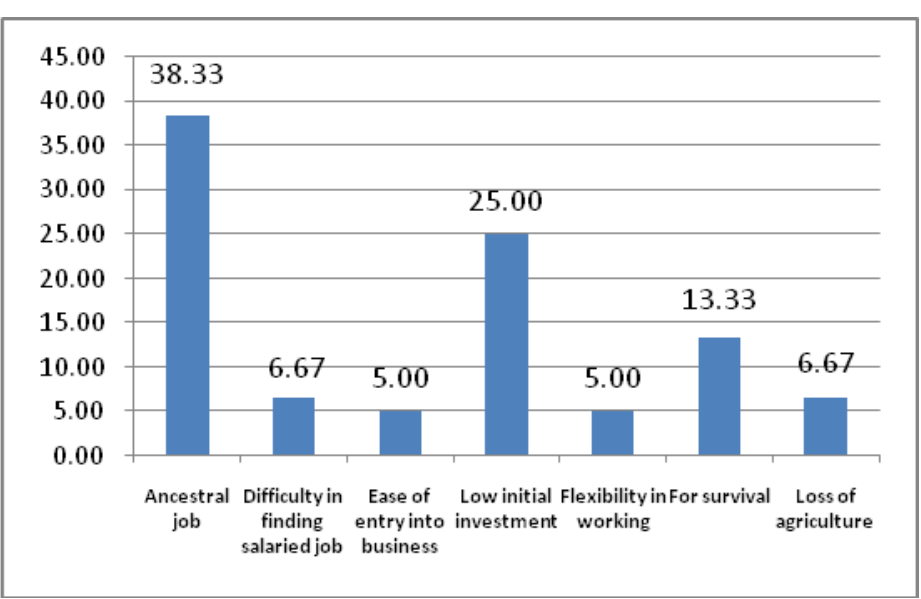


Majority of the respondents raised their capital for initial investment from individual savings, earned Rs. 100-300 per day and reported that the performance of their business was satisfactory. For majority of respondents the business of street vending was inherited from parents. Major constraints in street vending were fear of eviction by municipality officials, lack of formal license, lack of hygienic storage facilities, lack of permanent space for vending, price fluctuation, competition from other street vendors, organized retail sector and facing the adverse weather conditions.

Hence there is a need to provide legal status to the street vendors to enable them to carry on their business without fear of eviction. This can be done by formal licensing of the street vendors. Sufficient storage facilities also can be provided either on individual or group basis to avoid quantitative and qualitative losses to the fruits and vegetables. Competition among the street vendors can be minimized by organizing them in different localities so that they are evenly distributed in the city rather than concentrating in one area.

Since $81 \%$ of the Indian labour market is comprised of informal employment and street vending is one of the ways of selfemployment, providing the required support to the street vendors is essential to sustain their business and also to reduce unemployment in the economy.

\section{References}

Women and men in the informal economy: a statistical picture (third edition). International Labour Office - Geneva: ILO, 2018

https://thewire.in/labour/nearly-81-of-theemployed-in-india-are-in-the-informalsector-ilo
Transition from the Informal to the Formal Economy Recommendation, 2015 (No. 204): Workers' guide / International Labour Office, Bureau for Workers' Activities (ACTRAV). - Geneva: ILO, 2017.

https://unemploymentinindia.cmie.com/

https://www.thehansindia.com/posts/index/Ne ws-Analysis/2018-05-06/India-leadsworld-in-informalemployment/379153

Raveendran, G. 2011. Estimating domestic workers, home-based workers, street vendors and waste pickers in India.. Women in Informal Employment: Globalizing and Organizing (WIEGO).

Chen, Martha A. and G. Raveendran. 2011. Urban Employment in India: Recent Trends and Patterns. WIEGO Working Paper (Statistics) No. 7.

National Policy for Urban Street Vendors (NPUSV). Ministry of Urban Development \& Poverty Alleviation. Government of India; 2009. Available from:

http://www.muepa.nic.in/policies

http://nasvinet.org

http://www.fao.org/india/fao-in-india/india-ata-glance/en/

https://www.ibef.org/archives/detail/b3ZlcnZp ZXcmMzcxNTImNDk0

Arpita Mukherjee, Souvik Dutta and Tanu M. Goyal. 2016. Snapshot of Fruits and Vegetables Consumption, Availability and Implications for Phytonutrient Intake. India's Phytonutrient Report. Indian Council for Research on International Economic Relations (ICRIER)

http://www.tsccc.eptri.com/about/telangana

Kumar, P., \& Mathur, V. C. 1996. Structural changes in the demand for food in India. Indian Journal of Agricultural Economics. 51 (4): 664. 
Kumar, Praduman, Mruthyunjaya and Dey, Madan, M. 2007. Long-term changes in food basket and nutrition in India. Economic and Political Weekly. September (1): 3567-3572.

Mittal, S. 2007. What affects changes in cereal consumption? Economic and Political Weekly. 444-447.

Ray, R. 2007. Changes in Food consumption and the implications for food security and undernourishment: Indian in the 1990s. Development and Change. 38 (2): 321-343.
Sanjiv Kumar, Ranjit Kumar, Seema, A. Dhandapani, N. Sivaramane, PC Meena and P. Radhika. 2017. Food Consumption Pattern in Telangana State-2017. ICAR-National Academy of Agricultural Research Management, Hyderabad, India.

https://tmepma.cgg.gov.in/streetVendorsAllRe port.do

https://www.thehansindia.com/posts/index/Ne ws-Analysis/2018-05-06/India-leadsworld-in-informalemployment/379153

\section{How to cite this article:}

Samarpitha, A. 2019. Fruit and Vegetable Street Vendors in Urban Informal Sector in Hyderabad, India. Int.J.Curr.Microbiol.App.Sci. 8(11): 967-973.

doi: https://doi.org/10.20546/ijcmas.2019.811.113 